\title{
The Opportunity to Learn Euclidean Geometry in Two Mathematics Textbooks of Tenth Grade in South Africa
}

\author{
Ugorji I. Ogbonnaya ${ }^{1, a)}$ \\ ${ }^{1}$ University of Pretoria \\ Groenkloof Campus, George Storrar \& Leyds Street, Groenkloof, Pretoria 0002, South Africa \\ a) ugorji.ogbonnaya@up.ac.za
}

\begin{abstract}
Textbooks play a central role in the teaching and learning of mathematics. In some schools, textbooks serve as the only resource material available to teachers and students. Nevertheless, little is known about the learning opportunities in mathematics textbooks in most countries. This study investigated the opportunities to learn Euclidean Geometry in two textbooks of tenth-grade mathematics in South Africa. It examined the content coverage, content organization, and the types of tasks used in teaching the topic in the textbooks. This study followed a case study research design and a qualitative approach. The Curriculum and Assessment Policy Statement's (CAPS) grade 10 Euclidean geometry curriculum and Gracin's mathematical activity types served as frameworks for the analyses. The data were analyzed following the deductive content analysis approach. The result shows that the contents of Euclidean geometry were well covered in both textbooks following the curriculum, and the contents were presented in logical and sequential order to enhance learning. In addition, it was found that the tasks in the textbooks were predominantly of argumentation and reasoning type. It was concluded that the textbooks offer sufficient opportunities for learning Euclidean geometry as specified in the curriculum for the grade level. However, the inclusion of a broader range of tasks in the future editions of the textbooks was recommended.
\end{abstract}

Keywords: Euclidean Geometry; Mathematics Textbook; Opportunity to Learn

\begin{abstract}
Abstrak. Buku teks memainkan peran sentral dalam pengajaran dan pembelajaran matematika. Di beberapa sekolah, buku teks berfungsi sebagai satu-satunya bahan sumber yang tersedia bagi guru dan siswa. Namun, sedikit yang diketahui tentang peluang belajar dalam buku teks matematika di sebagian besar negara. Studi ini menyelidiki peluang untuk mempelajari Geometri Euclidean dalam dua buku teks matematika kelas sepuluh di Afrika Selatan. Ini memeriksa cakupan konten, organisasi konten, dan jenis tugas yang digunakan dalam mengajar topik dalam buku teks. Penelitian ini mengikuti desain penelitian studi kasus dan pendekatan kualitatif. Kurikulum geometri Euclidean kelas 10 dari Curriculum and Assessment Policy Statement (CAPS) dan jenis aktivitas matematika Gracin berfungsi sebagai kerangka kerja untuk analisis. Data dianalisis dengan pendekatan analisis isi deduktif. Hasilnya menunjukkan bahwa isi geometri Euclidean tercakup dengan baik di kedua buku teks yang mengikuti kurikulum dan isinya disajikan secara logis dan berurutan untuk meningkatkan pembelajaran. Selain itu, ditemukan bahwa tugas-tugas dalam buku teks sebagian besar bertipe argumentasi dan penalaran. Disimpulkan bahwa buku teks menawarkan kesempatan yang cukup untuk belajar geometri Euclidean sebagaimana ditentukan dalam kurikulum untuk tingkat kelas. Namun, dimasukkannya tugas yang lebih luas dalam edisi mendatang buku teks direkomendasikan.
\end{abstract}

Kata kunci: Buku Ajar; Geometri Euclid; Kesempatan untuk Belajar 


\section{INTRODUCTION}

Textbooks are vital resources in teaching and learning. They are used as familiar sources of information for the formal study of school subjects and instruments for teaching and learning (Graves, 2000; Sherman, Walkington \& Howell, 2016). They are avenues for knowledge acquisition for teachers and students; hence they are commonly used in teaching and learning in most schools in different countries (Van Steenbrugge, Valcke \& Desoete, 2013). As a fundamental resource, textbooks can shape the way a subject is taught and learned. They influence the teachers' instructional decisions because teachers often use textbooks to plan their lessons (Jones \& Tarr, 2007; Remillard \& Heck, 2014). Textbooks are expected to provide a framework for what is taught, how it may be taught, and in what sequence it may be taught (Lemmer, Edwards \& Rapule, 2008); they "are designed to translate the abstractions of curriculum policy into operations that teachers and students can carry out" (Valverde et al., 2002, p.2).

Due to the central role of textbooks in teaching and learning, textbooks used for teaching and learning must provide optimal opportunities for students to learn the curriculum content. The textbooks must provide explicit, correct content and instructional support to teachers and students (Lemmer, Edwards \& Rapule, 2008). The textbooks are essential regarding presenting important mathematics topics like Euclidean Geometry in textbooks used for teaching and learning.

Euclidean geometry studies planes and solid figures based on Euclid's axioms and theories (Artmann, 2020). It is a very significant branch of mathematics; hence, its study is included in the mathematics curricula of most countries, including South Africa (Fitriani, Suryadi \& Darhim, 2018; Shongwe, 2019). It is one of the topics in mathematics in the South African School curriculum (Curriculum and Assessment Policy Statement [CAPS]) that reinforces problem-solving through critical thinking (Department of Basic Education [DBE], 2011). In the curriculum (CAPS), the teaching of Euclidean proof starts in Grade 10, where the students are expected to investigate, make and prove conjectures about the properties of plane geometric figures ([DBE, 2011).

Due to the importance of Euclidean geometry in mathematics, the difficulties encountered by teachers and students in its teaching and learning, and the poor achievement of students on the topic (DBE, 2019), several research studies have explored, among others, teachers and pre-service teachers' knowledge of Euclidean geometry or difficulties they have in teaching it (Alex, 2019; Tachie, 2020; Ubah \& Bansilal, 2019), students' challenges in learning Euclidean geometry (Fitriani, Suryadi \& Darhim, 2018; Matheou, \& Panaoura, 2021; Ngirishi \& Bansilal, 2019; Shongwe, 2019), and impact of different teaching strategies and technologies on students' learning of Euclidean geometry (Adeniji, Ameen, Dambatta \& Orilonise, 2018; Bayaga, Mthethwa, Boss ̃̃ \& Williams, 2020; Mukamba \& Makamure, 2020). Nevertheless, the investigation of Euclidean geometry learning opportunities in teaching and learning materials seems to be lacking in 
mathematics education research, especially in the African context. As the textbook is practical teaching and learning resource in South Africa, it was found necessary to investigate the opportunity to learn Euclidean Geometry in mathematics textbooks.

Opportunity to Learn (OTL) is a way of measuring whether students have access to the different ingredients (e.g., content domains, cognitive skills, qualified teachers) that make for quality learning (Akiba, LeTendre \& Scribner, 2007; Hadar, 2017). OTL is used to determine whether students are provided with enough access and information to learn the curriculum for their age and grade level. According to McDonnell (1995), OTL was introduced as part of the First International Mathematics Survey in the early 1960s, but the concept was substantially refined in the Second International Mathematics Study (SIMS), conducted between 1976 and 1982. OTL includes the qualities and quantities of human and material resources available in schools, school conditions, and students' experience (Banicky, 2000). These issues are considered critical for students' learning and achievement (Mohale \& Mafumbate, 2019; Stols, Kriek \& Ogbonnaya, 2008). Hence, OTL includes students' access to qualified teachers, appropriate books and quality learning materials, quality teaching, and access to school conditions that provide them with enough opportunity to learn and achieve knowledge and skills. The OTL of a textbook measures what the textbook offers teachers and students for them to access the desired knowledge and skills in the intended curriculum (Hong et al., 2020; Otten et al., 2014). It includes the content covered in the textbook and the depth of coverage of the content (Charalambous, Delaney, Hsu \& Mesa, 2010).

Some studies have explored student opportunities to learn using different measures of OTL. For example, based on classroom instruction, Boston \& Wilhelm (2017) and Weiss, Pasley, Smith, Banilower, \& Heck (2003) used lesson observation to explore student opportunities to learn mathematics. Stols (2013) used students' workbooks to investigate the learning opportunities offered to Grade 12 mathematics students regarding content coverage, time on task, curriculum coherence, and cognitive demand of questions. Based on textbooks, Gracin (2018) explored the opportunity to learn mathematics available to students in grades 6-8 Croatian mathematics textbooks. Similarly, Hong and Choi (2018) studied the opportunity to learn linear functions available to students in Korean and American mathematics textbooks.

Textbooks are often considered expressions of the intended curriculum (what students are expected to learn) and are used to mediate the intended curriculum and the implemented curriculum (Hadar \& Ruby, 2019; Polikoff, 2015). Hence, textbooks influence the implemented curriculum, indicating student opportunities to learn the curriculum (Houang \& Schmidt, 2008). Student opportunity to learn in textbooks has been shown to relate to the students' mathematics performance (Wijaya, van den Heuvel-Panhuizen \& Doorman, 2015). Literature survey shows various ways researchers in mathematics education have explored OTL in textbooks. Stylianides 
(2009) analyzed reasoning-and-proving opportunities in US mathematics textbooks and found that the textbooks offered students limited opportunities to solve reasoning and proving problems. Similarly, Polikoff's (2015) analysis of textbooks' alignment to core curriculum standards in Florida, United States, showed that the three textbooks analyzed offered limited opportunities for students to learn problem-solving in that the textbooks "overemphasized procedures and memorization and underemphasize conceptual skills" (p.1206).

In their study on OTL available in textbooks, Van Zanten and van den Heuvel-Panhuizen (2018) explored OTL problem-solving in Dutch Grades 4 and 6 mathematics textbooks. The study showed that the textbooks offered minimal opportunities for students to learn problem-solving in that only $3-9 \%$ of tasks in the textbooks were found to be problem-solving tasks. Gracin (2018) analyzed the mathematical activities students need to engage in to do the tasks in the most used Grades 6-8 Croatian mathematics textbooks. Gracin found that the textbooks did not provide a full range of task types, and most of the tasks in the textbooks required computation. In a study with Grade 8 Arab community students in Israel, Hadar (2017) investigated the relationship between students' achievements in a national examination and the cognitive level opportunities provided in their mathematics textbooks. The study showed that the students' achievements at different cognitive levels correlated with the cognitive opportunities provided in their textbooks. In a similar study, Hadar and Ruby (2019) examined the cognitive demands of tasks in four different mathematics textbooks in Israel. They explored the level and complexity of understanding required to undertake the tasks successfully. The study found that the per cent of algorithmic tasks (requiring "ritual performances of algorithms and recall") in the textbooks ranged from $35.8 \%$ to $58.8 \%$. Furthermore, the study found that the tasks in all the textbooks mainly were understanding tasks of levels one ('present knowledge') and two ('act with or on knowledge'). The textbooks had very few tasks on level three ('criticize or create knowledge').

Wijaya, van den Heuvel-Panhuizen and Doorman (2015) analyzed the opportunity to solve context-based tasks available in three Indonesian mathematics textbooks. Their study showed that the textbooks did not give enough opportunity for context-based problem-solving. Also, the study showed that only $2 \%$ of the context-based tasks were reflection tasks (highest cognitive level). Reflection tasks are tasks "in which it is not obvious in advance what mathematical procedures have to be carried out" (Wijaya, van den Heuvel-Panhuizen \& Doorman, 2015, p.46).

The analysis of the opportunity to learn in a textbook could be a complex exercise, and various authors propose various frameworks, depending on the purpose of the analysis. The International Mathematics and Science Study (2002) provides a framework for textbook analysis that mathematics education researchers widely recognize as a tool for textbook analysis. The framework has three dimensions: Content (subject matter content), structure, and expectations 
(performance expectations). Content refers to subject topics and subtopics that are presented in a textbook. Structure refers to the content coherence of the topic presented in the textbooks. That is how ideas and concepts are organized and connected. The performance expectation is the expected student performance (Houang \& Schmidt, 2008). It is the cognitive behaviours and attitudes expected of students after learning the content from the textbook.

To explore OTL in a textbook, Charalambous et al. (2010) identified three categories of analyses, namely horizontal, vertical, and contextual analyses. "The horizontal analysis examines the general characteristics of textbooks, such as physical characteristics and the organization of the textbooks' content. This analysis gives a first impression of the OTL because it can provide information about the quantity of exposure of textbooks' content"(p.119). The vertical analysis addresses how textbooks present and treat the content. The vertical analysis offers an "in-depth understanding of the mathematical content. The third category, contextual analysis, focuses on how textbooks are used in instructional activities (Wijaya, van den Heuvel-Panhuizen \& Doorman, 2015 , p. 44). Charalambous et al. (2010) argued that only the horizontal and vertical analyses are appropriate to reveal the OTL in textbooks.

The objective of this study was to explore the opportunity to learn Euclidean Geometry in two Grade 10 textbooks. The focus was on the Euclidean geometry content coverage in the textbooks and the depth of coverage of the content. Content coverage measures the extent to which subject topics and subtopics prescribed in the curriculum are presented in the textbooks. The depth of coverage focused on the organization of content and the types of tasks used in teaching the content. Content organization is the sequence the textbooks present the mathematical concepts by making relevant links to foster content progression from past grade levels to the current grade level. It is the arrangement of the content in logical and sequential order to make sense and enhance connections between concepts. Charalambous, Delaney, Hsu, \& Mesa (2010) noted that the sequencing or ordering of contents could tell part of the story of the learning opportunities that textbooks can craft for students because "the selection and sequencing of topics not only frame what is to be learned but also could facilitate or impede this learning" (p.143). The types of tasks are mathematical activities, skills, or competencies required to do the tasks.

The following research questions were addressed to achieve the objective of this study: (i) what contents of Euclidean geometry are covered in the Grade 10 textbooks?; (ii) how are the topic contents organized in the textbooks?; and (iii) what types of mathematical tasks are used in teaching the topic in the textbooks? 


\section{METHOD}

This study followed a case study research design and a qualitative approach. It examined the Euclidean geometry content in the two textbooks of tenth-grade mathematics in South Africa. It also examined the types of tasks (explanation and exercises tasks) used to present the content in the textbooks. The qualitative approach was necessary to produce rich descriptive data concerning Euclidean geometry coverage in the textbooks (Yin, 2018). The two textbooks were Classroom Mathematics (Pike et al., 2011), identified here as Book1, and Platinum Mathematics (Campbell \& McPetrie, 2012), identified as Book2. The textbooks were purposively sampled for the study. They are approved for use in schools, and they seem to be the most popular and widely used mathematics textbooks in secondary schools in the country.

The Curriculum and Assessment Policy Statement's (CAPS) grade 10 Euclidean geometry content and organization were used as the yardstick for examining the content coverage and organization of Euclidean geometry in the textbooks. Deductive content analysis (Krippendorff, 2018) was used for the data analysis. Gracin (2018) four categories of mathematical tasks analytical framework (Table 1) were used to analyze task types in the textbooks.

Table 1. The Gracin (2018, p. 1009) mathematical task analytical framework

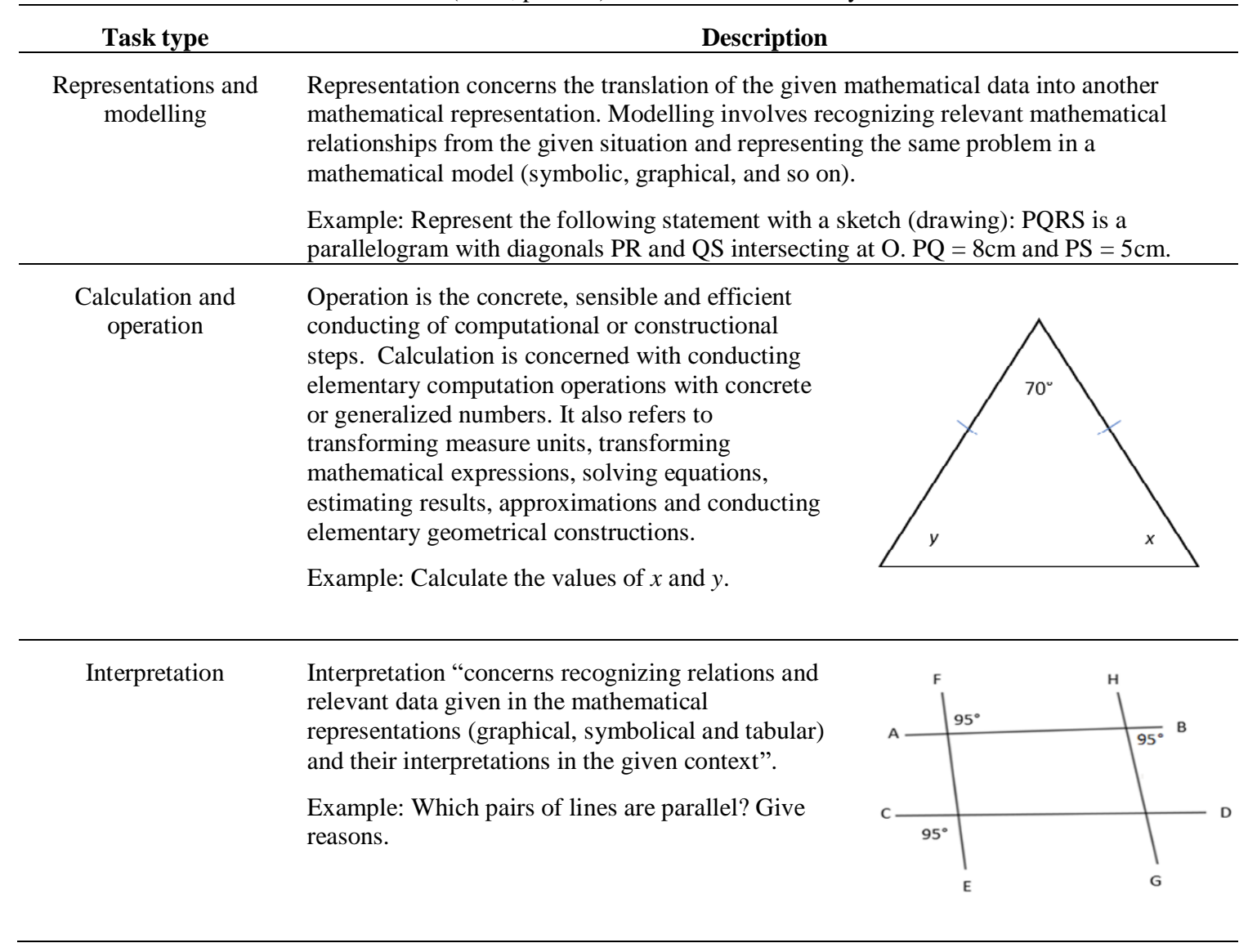


Argumentation and Argumentation "refers to the description of reasoning mathematical aspects that speak pro or contra a particular decision. It requires concrete and appropriate implementation of mathematical relations and characteristics, mathematical rules, as well as the correct usage of mathematical language. Reasoning concerns the sequence of true arguments that lead to a conclusion".

Example: $\mathrm{ABCD}$ is a parallelogram, $\mathrm{AC}$ and $\mathrm{BD}$ are equal, prove that $\mathrm{ABCD}$ is a rectangle.

All the explanation tasks (that is, solved examples tasks used in explaining the concepts) and exercise tasks on Euclidean geometry in the textbooks were analyzed concerning the mathematical activities, skills, or competencies required to do the tasks.

Two experienced mathematics teachers and researchers independently conducted the analysis. To evaluate the topic content coverage in the textbooks, the analysts used a list of the curriculum content as the checklist to indicate the topics covered in each textbook. There was a 100 per cent agreement in the analysts' views on the contents covered in both textbooks. Concerning the content organization, the analysts used flow diagrams to present the organization of the contents in both textbooks. There was also a complete agreement in the analysts' views on the organization of the contents in both textbooks.

There was an agreement between the analysts on 30 of 32 explanation (solved example) tasks in both textbooks on the task types. On the 144 exercise tasks in Book1, there were 140 (97\%) agreements in the analysts' classifications of the tasks according to types. On Book2's 186 exercise tasks, there was 182 (98\%) agreement on the analysts' classifications of the types of tasks. On the tasks that there were no agreements on the analysts' classifications, they discussed the tasks and arrived at a consensus.

\section{RESULTS AND DISCUSSION}

Euclidean geometry content is presented in chapters 9 and 14 (pages 195 - 224 and $327-342$ respectively) in Book 1, and topics 6 and 10 (pages 161 - 181 and 245 - 252 respectively) in Book 2. The distribution of the Euclidean geometry tasks in the textbooks is shown in Table 2.

Table 2. Distribution of Euclidean geometry tasks in the textbooks

\begin{tabular}{ccc}
\hline & Book 1 & Book 2 \\
\hline Explanation tasks & 15 & 17 \\
\hline Exercises tasks & 144 & 186 \\
\hline Total & 159 & 203 \\
\hline
\end{tabular}

The findings are presented according to the three aspects of OTL in this study: content coverage, content organization, and types of tasks. 


\section{Content Coverage}

According to the mathematics curriculum (DBE, 2011), the contents expected to be covered in Grade 10 under Euclidean are:

(i) Revision of preliminary results: lines, angles, triangles, similarity, and congruence.

(ii) Investigation of line segments joining the midpoints of two sides of a triangle,

(iii) Definition of the following special quadrilaterals: the kite, parallelogram, rectangle, rhombus, square and trapezium,

(iv) Investigation and making conjectures about the properties of kite, parallelogram, rectangle, rhombus, square and trapezium,

(v) Prove the conjectures in iv,

(vi) Solve problems and prove riders using the properties of parallel lines, triangles, and quadrilaterals

It was found that the six contents listed above were covered in the textbooks. However, the investigation and making conjectures about the properties of a trapezium (part of the fourth content) and prove of conjectures about the properties of square and trapezium (part of the fifth content) were not explicitly covered in Book1 and Book2 respectively. In Book2, solving problems and proving riders using the properties of parallel lines, triangles, and quadrilaterals were not presented in solved examples but were found in exercises. In both textbooks, the concepts were explained in detail, and diagrams were used in almost all cases though Book1 seems more detailed. Book2 used real-life examples (pictures of animals) to explain and contextualize similarity and congruency.

\section{Content Organization}

The contents of Euclidean geometry were presented in two chapters in each of the textbooks. Figure 1 shows the order of presentation of the contents of Euclidean geometry in the textbooks. The organizations of the contents were similar in both textbooks. It was found that the organization of contents in the textbooks, from the revision of properties of lines, angles, and polygons to geometric proofs, was in a sequential and logical order to enhance the making of connections between the concepts. This sequencing shows coherence as the proceeding contents build on the knowledge from the preceding contents. 
EDUMATIKA : Jurnal Riset Pendidikan Matematika

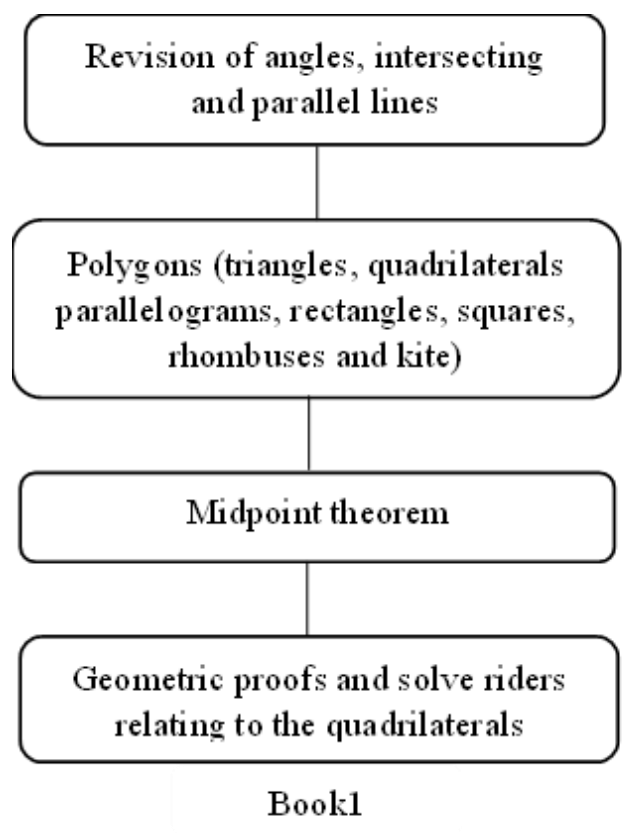

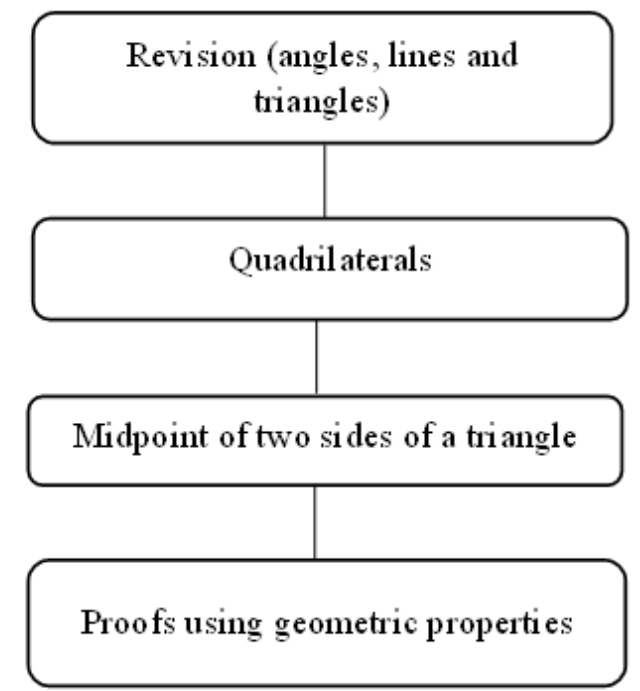

Book2

Figure 1. The topics and their order of presentations in the textbooks

\section{Types of Tasks}

Both textbooks used mainly argumentation and calculation tasks in teaching the topic (See Figure 2). There were 15 solved example tasks in Book1. Of the 15 tasks, 11 (73\%) were argumentation type while 4 (27\%) were calculation type. Book1 did not have any interpretation and representation tasks in the worked examples. Book1 had 54 exercise questions made of 144 tasks. Most of the tasks (88 accounting for 61\%) were argumentation type, 38 (26\%) were of calculation and operation type, while $17(12 \%)$ and 1(approximately $1 \%)$ were interpretation and representation types, respectively.

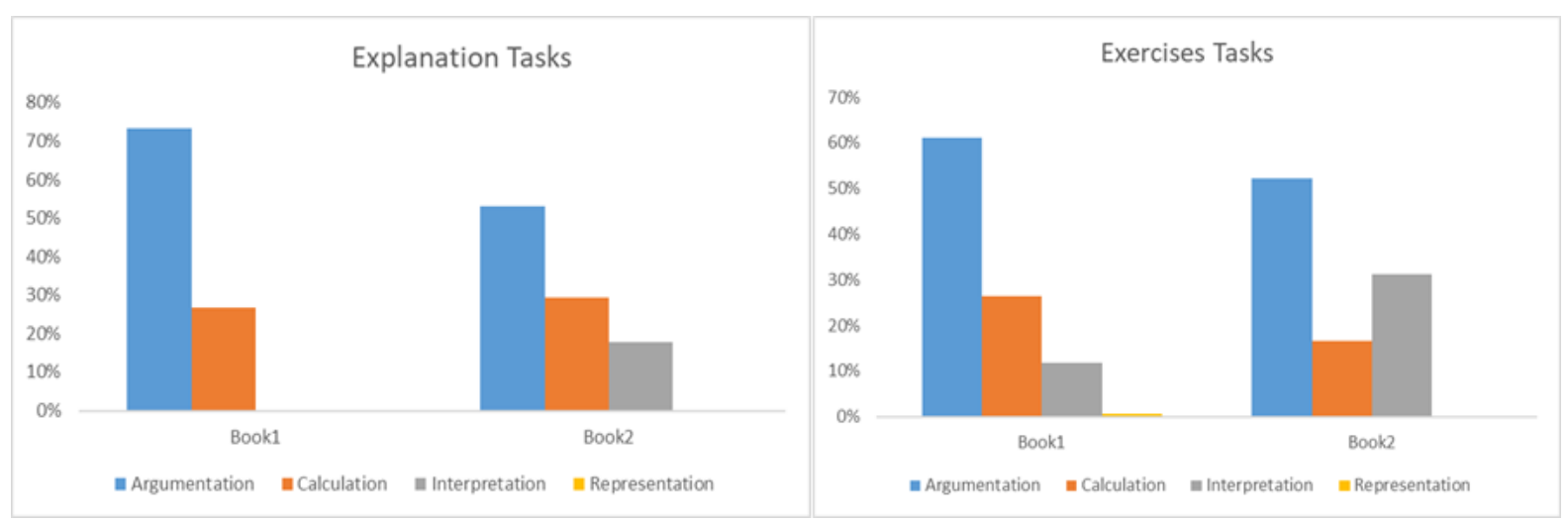

Figure 2. Percentages of the types of tasks in the textbooks

Book 2 used six solved examples in teaching the topic. The six examples were made up of 17 tasks. Nine (53\%) of them were argumentation type, five (29\%) were calculation type, and three (18\%) were interpretation type of question. There were 74 exercise questions made of 186 tasks in Book2. Most of the tasks (97 accounting for 52\%) were of argumentation type, 31 (17\%) were of 
calculation and operation type, while the remaining $58(31 \%)$ were interpretation type. None of the tasks was of representation type.

This study explored the opportunity to learn Euclidean geometry in two grade 10 South African textbooks, focusing on the content coverage, content organization, and the types of mathematical tasks in the textbooks. The content presented on a topic serves as an indicator of what students would learn if the teaching of the topic in their classes covered all the content (Mesa, 2004). Both textbooks presented just about the same Euclidian geometry content and were organized in the same order. Both books started with the revision of angles and lines from previous grade levels followed by polygons (triangles and quadrilateral in book 1) and quadrilateral (in Book 2); the following content presented was the Midpoint theorem (in both books) and finally, Geometric proofs (also in both books). Starting the content with the revision of some contents from previous grade levels was necessary to lay a foundation and transition to the grade 10 work. Except for the detailed presentations of the investigation and making conjectures about the properties of a trapezium in Book1 and prove of conjectures about the properties of square and trapezium in Book2, the presentations of quadrilateral, midpoint theorem, and Geometric proofs in both textbooks is an indication that both textbooks addressed the core content of grade 10 Euclidian geometry specified in the curriculum.

The organization of the contents in both books seems to respond to the order of the topic contents in the curriculum except for the swapping of the midpoint theorem and definition of quadrilaterals. In the curriculum, the midpoint theorem comes before the definition of quadrilaterals, while the definition of quadrilaterals is presented before the textbook's midpoint theorem. The authors might have placed the midpoint theorem after the definition of quadrilaterals to allow for an immediate application. It might also be that the authors wanted to place the midpoint theorem directly before the geometric proofs as a precursor for exploring the geometric proofs. The sequencing of the content in a mathematics textbook must have some underlying mathematical and pedagogical philosophy that the author believes will help interpret the content and render it teachable and comprehensible by the student (Dewey, 1906 in Charalambous et al., 2010). The sequencing of content in the textbooks shows the progression from simple to complex as espoused in the curriculum (DBE, 2011). This, from both mathematical and pedagogical perspectives, might make the contents easy to teach and accessible to students.

Both textbooks offered substantial numbers of worked examples and exercise tasks on the topic. Regarding the mathematical activities, skills, or competencies required to do the tasks, the tasks (worked examples and exercises) in both textbooks were mainly of argumentation and calculation types. The textbooks did not provide a full range of task types to give the optimal opportunity for students to learn the topic. This finding parallels the findings of Gracin (2018) in 
his analysis of the types of tasks in some grades 6-8 Croatian mathematics textbooks. In this study, the argumentation and calculation tasks constituted $100 \%$ and $87 \%$ of worked examples and exercises tasks respectively in Book1, and $82 \%$ and $69 \%$ of the worked examples and the exercises tasks respectively in Book2. Book1 did not offer any interpretation or representation types of tasks in its worked examples, although $12 \%$ of the exercises were interpretation and $1 \%$ was representation type. Book 2 offered $18 \%$ and $31 \%$ interpretation tasks in the worked examples and the exercises, respectively but did not include any representation type of task in both the worked examples and the exercises.

The dominance of argumentation and calculation tasks (especially argumentation tasks) in both textbooks might, however, be in response to the Grade 10 Euclidean geometry curriculum emphasis on investigating, making, and proving conjectures and theorems. Hence, the finding could suggest the textbooks' authors' thorough interpretation of the curriculum and their belief that Euclidean geometry is mainly about calculating sides and angles, investigating, making, and proving conjectures and theorems. Nevertheless, using worked examples and exercises that draw from multiple types of tasks would afford students more opportunities to develop a more complex, connected, and robust understanding of the content (Charalambous et al., 2010).

\section{CONCLUSIONS}

This study explored the OTL Euclidean Geometry available in two textbooks of tenth-grade mathematics. Specifically, it explored the content coverage, organization, and mathematical tasks used to teach the topic. The study found similarities in the content coverage and organization of the content in the textbooks. As specified in the curriculum, the topic contents were well covered in both textbooks, and the contents were presented in logical and sequential order. Besides, it was found that the tasks in the textbooks were predominantly argumentation and calculation type. In all, the textbooks were found to offer sufficient opportunities for learning Euclidean geometry as specified in the curriculum for the grade level. However, the author recommends including a broader range of tasks in the future editions of the textbooks. This research will likely help the teachers to use a broader range of mathematical tasks in teaching the topic and consequently enhance the Euclidean geometry learning opportunities of the students.

\section{REFERENCES}

Adeniji, S. M., Ameen, S. K., Dambatta, B. U., \& Orilonise, R. (2018). Effect of Mastery Learning Approach on Senior School Students' Academic Performance and Retention in Circle Geometry. International Journal of Instruction, 11(4), 951-962. https://doi.org/10.12973/iji.2018.11460a

Akiba, M., LeTendre, G. K., \& Scribner, J. P. (2007). Teacher quality, opportunity gap, and national achievement in 46 countries. Educational Researcher, 36(7), 369-387. https://doi.org/10.3102/0013189X07308739 
Alex, J. K. (2019). The Preparation of Secondary School Mathematics Teachers in South Africa: Prospective Teachers' Student Level Disciplinary Content Knowledge. Eurasia Journal of Mathematics, Science and Technology Education, 15(12), em1791. https://doi.org/10.29333/ejmste/105782

Artmann, B. (2020, September 10). Euclidean geometry. Encyclopedia Britannica. https://www.britannica.com/science/Euclidean-geometry

Banicky, L. (2000). Opportunity to learn. Education Policy Brief, 7. Retrieved from https://udspace.udel.edu/bitstream/handle/19716/2446/opp\%20to\%20learn.pdf?sequence=1

Bayaga, A., Mthethwa, M., BossÃ, M., J. \& Williams, D. (2020). Impacts of implementing GeoGebra on eleventh grade students learning of Euclidean Geometry. South African Journal of Higher Education, 33(6), 32-54. https://doi.org/10.20853/33-6-2824

Boston, M. D. \& Wilhelm, A. G. (2017). Middle School Mathematics Instruction in Instructionally Focused Urban Districts. Urban Education, 52(7), 829-861. https://doi.org/10.1177/0042085915574528

Campbell, J. \& McPetrie, S. (2012). Platinum Mathematics Grade 10 Learner's Book. Cape Town, South Africa: Maskew Miller Longman

Charalambous, C. Y., Delaney, S., Hsu, H.Y., \& Mesa, V. (2010). A comparative analysis of the addition and subtraction of fractions in textbooks from three countries. Mathematical Thinking and Learning, 12(2), 117-151. https://doi.org/10.1080/10986060903460070

Department of Basic Education. (2011). Curriculum Assessment Policy Statement grades 10 to 12 Mathematics. Pretoria Department of Basic Education.

Department of Basic Education, (2019). National Senior Certificate Diagnostic Report: Part 1. Retrieved from: https://www.education.gov.za/Resources/Reports.aspx

Fitriani, N., Suryadi, D. \& Darhim, D. (2018). Analysis of mathematical abstraction on concept of a threedimensional figure with curved surfaces of junior high school students. Journal of Physics: Conference Series, 1132, 1-7. https://doi.org/10.1088/1742-6596/1132/1/012037

Gracin, D. G. (2018). Requirements in mathematics textbooks: a five-dimensional analysis of textbook exercises and examples. International journal of mathematical education in science and technology, 49(7), 1003-1024. https://doi.org/10.1080/0020739X.2018.1431849

Graves, K. (2000). Designing Language Course, A Guide for Teachers. Boston. Heinle. Cengage Learning.

Hadar, L. L. (2017). Opportunities to learn: Mathematics textbooks and students' achievements. Studies in Educational Evaluation, 55 (2017), 153-166. https://doi.org/10.1016/j.stueduc.2017.10.002

Hadar, L. L. \& Ruby, T. L. (2019). Cognitive opportunities in textbooks: the cases of grade four and eight textbooks in Israel. Mathematical Thinking and Learning, 21(1), 54-77. https://doi.org/10.1080/10986065.2019.1564968

Hong, D. S. \& Choi, K. M. (2018). A comparative analysis of linear functions in Korean and American standards-based secondary textbooks. International journal of mathematical education in science and technology, 49(7), 1025-1051. https://doi.org/10.1080/0020739X.2018.1440327

Hong, D. S., Choi, K. M., Runnalls, C. \& Hwang, J. (2020). Examining curricular coverage of volume measurement: A comparative analysis. International Journal on Social and Education Sciences, 2(1), 1-19. https://www.ijonses.net/index.php/ijonses/article/view/22/18

Houang, R. T., \& Schmidt, W. H. (2008). TIMSS international curriculum analysis and measuring educational opportunities. 3rd IEA International Research Conference. Taipei: Chinese Taipei. Retrieved from https://www.iea.nl/publications/presentations/timss-international-curriculumanalysis-and-measuring-educational

Jones, L. D. \& Tarr, J. E. (2007). An examination of the levels of cognitive demand required by probability tasks in middle grades mathematics textbooks. Statistics Education Research Journal, 6(2), 4-27. https://www.stat.auckland.ac.nz/ iase/serj/SERJ6(2)_Jones_Tarr.pdf

Krippendorff, K. (2018). Content analysis: An introduction to its methodology (4th ed.). California: Sage. 
Lemmer, M., Edwards, J. \& Rapule S. (2008). Educators' selection and evaluation of natural sciences textbooks. South African Journal of Education, 28,175-187. Retrieved from: https://files.eric.ed.gov/fulltext/EJ1149996.pdf

Matheou, A. A., \& Panaoura, R. (2021). Young Students'Ability on Understanding and Constructing Geometric Proofs. Social Education Research, 2(2), 121-133. https://doi.org/10.37256/ser.222021784

McDonnell, L.M. (1995). Opportunity to Learn as a Research Concept and a Policy Instrument. Educational Evaluation and Policy Analysis, 17(3), 305-322. https://doi.org/10.3102/01623737017003305

Mesa, V. (2004). Characterizing practices associated with functions in middle school textbooks: An empirical approach. Educational Studies in Mathematics, 56, 255-286. https://link.springer.com/article/10.1023/B:EDUC.0000040409.63571.56

Mohale, N. \& Mafumbate, R. (2019). Effects of Resource Materials on Implementation of Life Skills Education Programme in Manzini Region High Schools of Eswatini. Journal of Education and Practice, 10(27), 46-53. https://www.iiste.org/Journals/index.php/JEP/article/view/49710/51357

Mukamba, E., \& Makamure, C. (2020). Integration of GeoGebra in Teaching and Learning Geometric Transformations at Ordinary Level in Zimbabwe. Contemporary Mathematics and Science Education, 1(1), ep20001. https://doi.org/10.30935/conmaths/8431

Ngirishi, H., \& Bansilal, S. (2019). An exploration of high school learners' understanding of geometric concepts. Problems of Education in the 21st Century, 77(1), 82-96. https://doi.org/10.33225/pec/19.77.82

Otten, S., Gilbertson, N. J., Males, L. M., \& Clark, D. L. (2014). The Mathematical Nature of Reasoning-and proving Opportunities in Geometry Textbooks. Mathematical Thinking and Learning, 16(1), 51-79. https://doi.org/10.1080/10986065.2014.857802

Pike, M., Barnes, H., Jawurek, A. Kitto, A., Laridon, P., Myburgh, M., Rhodes-Houghton, R., Scheiber, J., Sigabi, M. \& Wilson, H. (2011). Classroom Mathematics Grade 10, Learner's book. Sandton, South Africa: Heinemann Publishers

Polikoff, M. S. (2015). How well aligned are textbooks to the common core standards in mathematics? American Educational Research Journal, 52(6), 1185-1211. https://doi.org/10.3102\%2F0002831215584435

Remillard, J. T. \& Heck, D. J. (2014). Conceptualizing the curriculum enactment process in mathematics education. ZDM, 46(5),705-718. https://link.springer.com/article/10.1007/s11858-014-0600-4

Sherman, M. F., Walkington, C., \& Howell, E. (2016). Brief report: A comparison of symbol-precedence view in investigative and conventional textbooks used in algebra courses. Journal for Research in Mathematics Education, 47(2), 134-146. https://doi.org/10.5951/jresematheduc.47.2.0134

Shongwe, B. (2019). The quality of argumentation in a Euclidean geometry context in selected South African high schools: validation of a research instrument. In N. Govender, R. Mudaly, T. Mthethwa \& A. Singh-Pillay (Eds.), Research for inclusive, relevant, and equitable quality Mathematics, Science and Technology Education: Promoting research-based opportunity for all. Proceedings of 27th Annual Conference of the Southern African Association for Research in Mathematics, Science and Technology Education (pp. 98-112). Durban, South Africa

Stols, G. (2013). An investigation into the opportunity to learn that is available to Grade 12 mathematics learners. South African Journal of Education, 33(1), 1-18. http://www.scielo.org.za/scielo.php?script=sci_arttext\&pid=S0256-01002013000100006

Stols, G., Kriek, J. \& Ogbonnaya, U. I., (2008). The relationship between teaching practices and students' achievement in mathematics in Lesotho. African Journal of Research in Mathematics, Science and Technology Education, 12 (special issue), 107-118. https://hdl.handle.net/10520/EJC92689

Stylianides, G. J. (2009). Reasoning-and-proving in school mathematics textbooks. Mathematical Thinking and Learning, 11(4), 258-288. https://doi.org/10.1080/10986060903253954

Tachie, S. A. (2020). The challenges of South African teachers in teaching euclidean geometry. International Journal of Learning, Teaching and Educational Research, 19(8), 297-312. https://doi.org/10.26803/ijlter.19.8.16 
Ubah, I., \& Bansilal, S. (2019). The use of semiotic representations in reasoning about similar triangles in Euclidean geometry. Pythagoras, 40(1), a480. https://doi.org/10.4102/pythagoras.v40i1.480

Valverde, G., Bianchi, L., Wolfe, R., Schmidt, W. \& Houang, R. (2002). According to the Book: Using TIMSS to Investigate the Translation of Policy into Practice through the World of Textbooks. London: Kluwer Academic Publishers.

Van Steenbrugge, H., Valcke, M., \& Desoete, A. (2013). Teachers' views of mathematics textbook series in Flanders: Does it (not) matter which mathematics textbook series schools choose? Journal of Curriculum Studies, 45(3), 322-353. https://doi.org/doi:10.1080/00220272.2012.713995

van Zanten, M. \& van den Heuvel-Panhuizen, M. (2018). Opportunity to learn problem-solving in Dutch primary school mathematics textbooks, ZDM 50(5), 827-838. https://doi.org/10.1007/s11858-018$\underline{0973-\mathrm{X}}$

Weiss, I. R., Pasley, J. D., Smith, P. S., Banilower, E. R., \& Heck, D. J. (2003). Looking inside the classroom: A study of K-12 mathematics and science education in the United States. Chapel Hill, NC: Horizon Research, Inc.

Wijaya, A., van den Heuvel-Panhuizen, M. \& Doorman, M. (2015). Opportunity-to-learn context-based tasks provided by mathematics textbooks. Educ Stud Math, 89, 41-65. https://doi.org/10.1007/s10649$\underline{015-9595-1}$

Yin, R. K. (2018). Case study research and applications: Design and methods (6th ed). California: SAGE Publications. 